\title{
造塊用鲦再の諸問題
}

\section{毛利定 男*}

\section{はしがき}

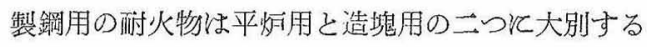
ことが出来る. 平物用の耐火物㵊近非常に進歩し て, 消耗の原单位も著しく減少して来た. 平炉の操業 《重油の採用, 計器操業, 酸絜の利用, 塩基性煉瓦の 准步と艺の利用, 天井用理石煉瓦の品筫の向上，焒体 設計の進歩等のためと年を追って合理化せられ 1 時間 当りの出鋼トン数, 出銅トン当りの消覧熱量, 鋼塊卜 ン当りの炣材原単位等の操業数字《物いて世界的レベ ル飞まで羍している工場す相当出るようになって来た が，造塊作業方面でねなだ相当問題が残されているよ 弓江思うので，以下造塊用煉瓦の現状と今後研究を要 する問題点について少し述べたい。

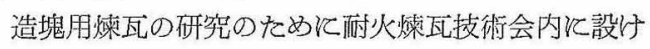
られた造塊用煪瓦專門委員会は鉄鎆側，而扵火煉瓦製造 側和よび学識経験者の委員が現在合計 70 名に達し, 年 2 回委員会を開催して研究学進好ている。造塊用啾 瓦は分類上鍋畨瓦，スリーブ，ノズル，ストッパー特 よび湯道煉瓦に分けららるが，鍋煉瓦以外のるのは使 用 1 回限りのものである。造塊用整瓦研究の目標とし ては銅塊の歩留りの向上，炬材の原单位の低下(鍋槵 瓦), 湯の清浄化すなるち秒㽞みの防止等が主な問題で 岕る。

\section{（1）鍋 煉 瓦}

鍋䍰瓦は数年来使用方法の改善（鍋の中の鉱橴の量 の調節等）と燌瓦品質の改良の両者相まって寿命が逐 次政長されると同時に原単位が低下乙て来た。第 1 図 络鍋煉瓦の原単位の全国平均である。䀡和 25 年の良

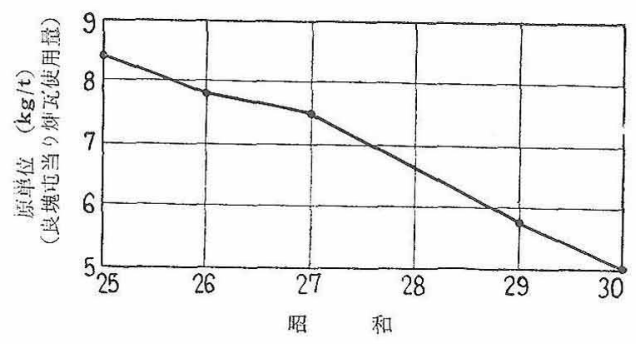

符 1 図浴煤瓦原単位全国平均

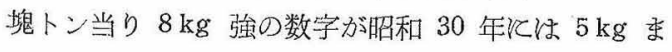
で低下している.この数字は炊米の水準と比較しても

* 品川白罾瓦㧣式会社常務取締役

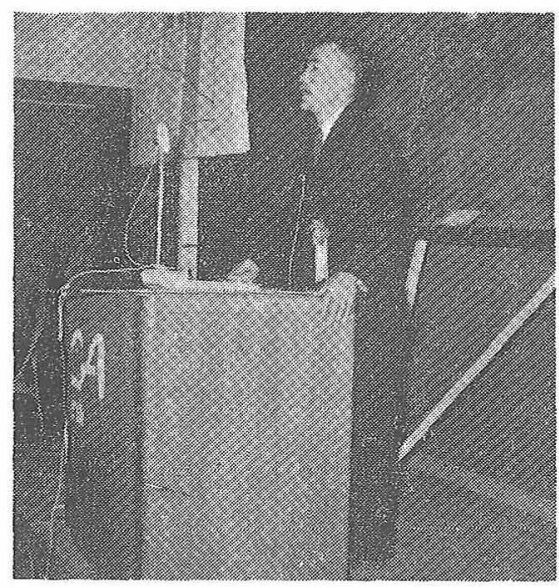

講演中の著者

そん色のない原単位に来ているるのと思われる。第 1 図㤔火煉瓦技術会造堄用煉瓦專門委員会で調查した 全国平炡工場の平均である.

鍋煉瓦の損傷の原因は鉱涬による侵能，熔銅炕よる

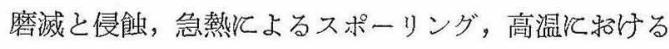
瑓瓦の収縮放裂, 目地部分からの侵蝕等です る、今まで行われて来て品筫改良の動向は附火度を第

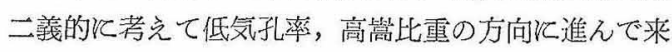
ている。これは欧米の進歩の方向と大怵同傾向とある ようである。このために虾適当な原料の選択と粘度調

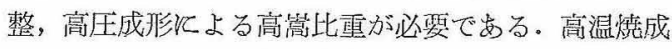
によって低気孔率党得る方法は賢明な方法ではある が，原料飞よって燒成温度飞限度があるから高温燒成 のみによる低気孔率の组いは無理の点がある。現在鍋

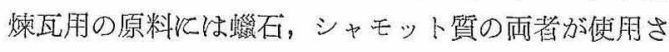
れている。

第 1 表は外国の鍋燌瓦品質の一例で岕る。耐火度は 相当低いるのがあり，かが国と同様重要視していない ことがらかがわれる. 共通的の傾向としては気孔率の 低いととで $20 \%$ 以下である。したがって简比重が 2 以上Kなり圧縮強さも高くなっている。興味のある点 としてはアメリカの鍋煤瓦の軟化点が低く $1500^{\circ} \mathrm{C}$ の

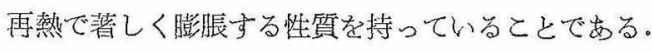
これは後述するブローチング (bloating) 性の原料を 使用している. 三，三の平炡会社でアメリカやドイッ の鍋炴瓦を輸入して内地煉瓦との比較試験が行われた が，現在のととろ甲乙の判定はつけ難いとのととであ る・低耐火度ブローチング性の鍋煉瓦の特長としては 
第 1 表 外国銅煤瓦品質の一例

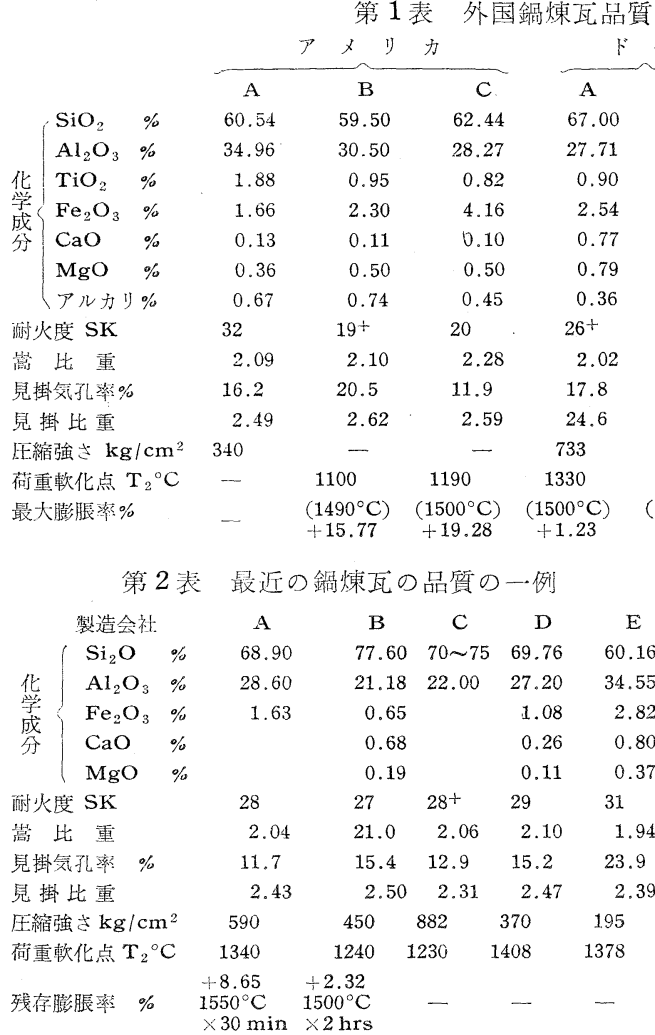

(1)高温で収縮しない，(2湯と煉瓦の接触面飞液相が出 来て表面が滑らか侵される，(3)使用中伤裂が出来 ても龟裂面が半粘稠性の液体でカバーされる，(4)目地 部分が収縮してもその鄚間がカバーされる等が考兄ら れる。乙かし，乙の特徵が砂㗪みの問題飞好影響を括 よぼすかどうかはまだ士分に探求されていない。鍋の 寿命と鋼塊品質飞挌よぼす影響との両面から考克て, ブローチング性の鍋徚瓦が良いかあるいはアルミナ分 が少し高くてブローチングしない低気孔率の煉瓦が良 いかの点も今後の研究問題である.とれで鍋煉瓦の品 質の如何なるるのが良いか，鍋鈥瓦の良否を判定する 方法として外国でも種々研究が発表されている。種々 の要因が多いから必要な判定尺度を定めるにあたり相 当回数の実験飞基づいて一つの方式を決めるのも興味 ある方法と思われる。

第 2 表は現在内地の各社で製造されている鍋煉瓦の 代表的品種の一例である. A, B,C,D は低耐火度高珪 酸質のもので気孔率は著しく低い。特飞A 品と同様にブロ一チング性の特色を示している。 E 普通のシャモット系のものである.

第 2 図 ${ }^{11}$ は 1952 年 9 月に開かれたドィツ鉄冶金協 会製鋼委員会炕提出された報告から引用したものであ るが, 品質係数 (Gütekennzahl) を定めて，乙れと 原単位との間の関係を示している。これはドィッの 60７0トン程度の鍋を使っている 17 工場のデータを
集計したもので, 鍋 1 基当りの銛涬量を平筑: 7.7 トンと統計的㳊推 定乙銅の平均炭素含有 量, 鍋 1 基当りには入 った鉣㳯の量と鍋の栔: 命から品質係数を計算 したものである.同时 飞品質係数之鋼煉瓦门 諸特性すなわち吸水 率, 気孔率, 荷重軟化 範囲 $\left(t_{e}-t_{a}\right)$, 圧縮強 さ,アルミナ百分率等 との関係を調査している. その結論として品質係数 200 以上の值をもつ煉瓦を使用するととが望ましいと している. そのためには圧縮強さは $260 \mathrm{~kg} / \mathrm{cm}^{2}$ 以上 が必要であり， $t_{e}-t_{a}$ 值は狭い程良いが $130^{\circ} \mathrm{C}$ 以下 が良い，すなわち良く焼成されると結果が良い，吸水 率は $8 \%$, 全気孔率は $22 \%$ 以下なるととが必要であ る. 200 以上の品質係数の煉瓦を使用するととによっ て良塊トン当りの煉瓦原単位を $8 \mathrm{~kg} / \mathrm{t}$ から $5.8 \mathrm{~kg} / \mathrm{t}$ 飞低減している。

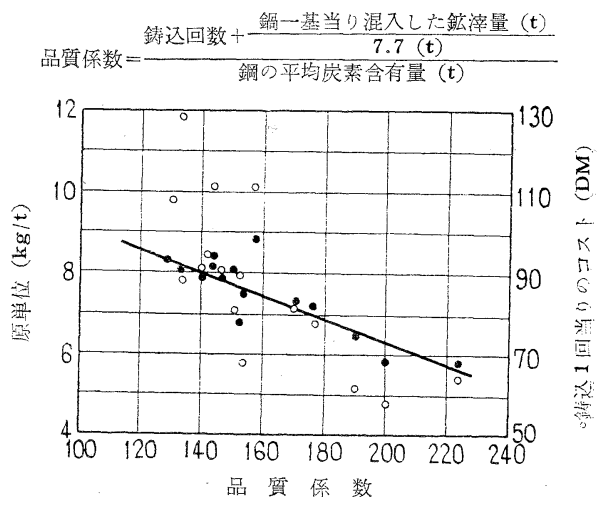

第 2 図品質係数と棟瓦原単位及び鋳造 1 回 当りコストとの間の図係

次にフランスの一製鋼技術者以品質係数 ${ }^{2)}$ (Quality index）を次式のように定義して，製鋼工場での操業 実績に基づいて第 3 図のような結果を得ている。

$$
I=2(P / D+100 p)+10,000 / 2 R \pm 2 \mathrm{~V}
$$

ここV

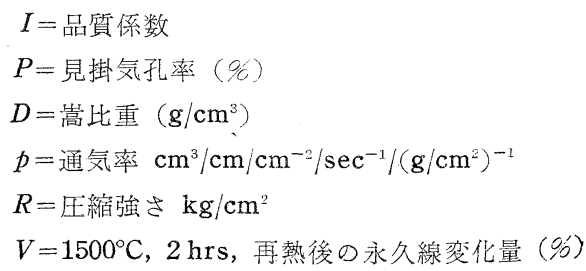

$V$ の前の係数は収縮の時正，膨脹の時負と する（膨脹の方が望ましいから） 

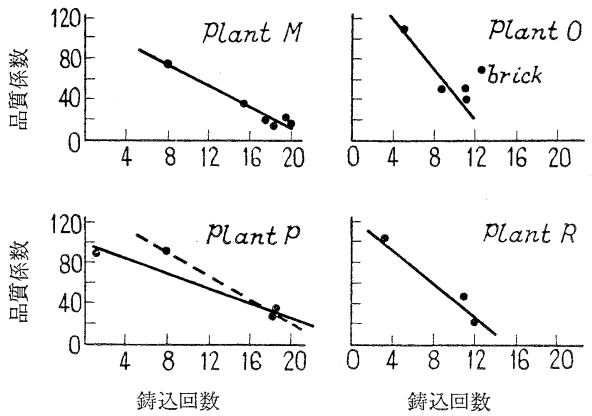

第 3 図 種々の工場で得られた鍋煉瓦寿命と 品質係数との間の関係 化量を考虑した点に興味がある、第 2 図の場合とは反 対品質係数の小さい程結果の良好なととを示してい る.

鎝煉瓦に関して今後に残された問題としては, 砂嚙 みと鍋煉瓦品質との関係（特殊鋼の場合にはこの点特 飞重要である），目地材料の品質の研究沶よび鍋煉瓦 形状の標準化の問題等がある.

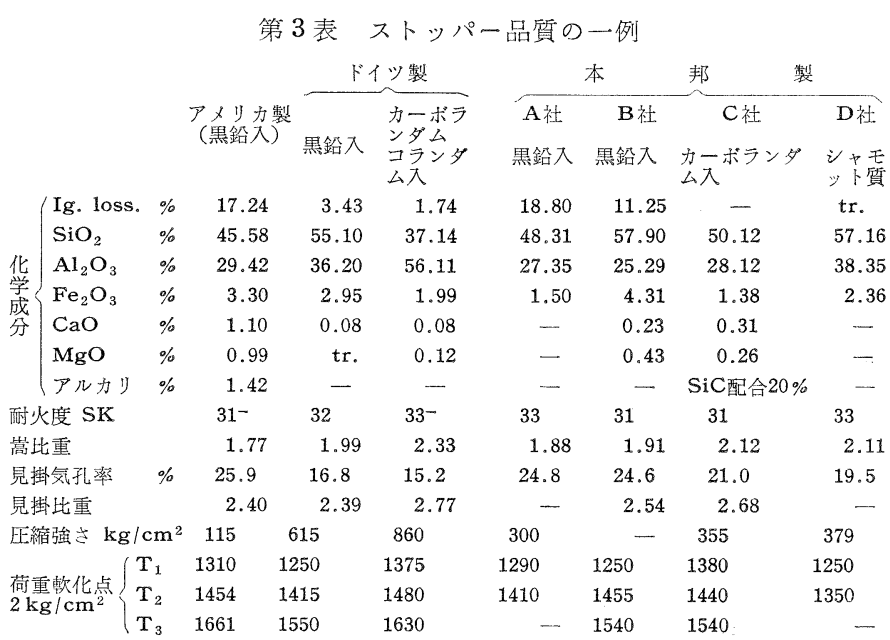

この品質係数は通気率と $1500^{\circ} \mathrm{C}$ 亿和ける再熱線変

\section{（2）ノズル，ストッパー}

ノズル，ストッパーは周知のように造塊作業の生命 とされている煉瓦で, 粘土質煉瓦のうちでは最も難物 視されている。最近は造塊作業に対する要求が漸次過 酷となり，湯止りが完全に 100\%:であるととを要求さ れている. そのために(1)スッパーはたとえ侵蝕され ても均一な侵蝕で片減りしてはいけない, (2)もちろん 使用時には少しの亀裂も許されない, (3)ノ゙ルは口佳 の桩大率少くかつ真円でなければならない等の諸条件 が満足されることを要求されるのでノズル，ストッパ 一の品質の改良, 形状の研究が数年来製造者側と使用 者側両者の共同研究の課題となって来ている.

以前はノズルとストッパーとは同品質のもので作ら れることが普通であったが，最近では湯止りを完全に するためにストッパーとノズルとの高温に拈ける硬さ を変觉る，すなわらどららかを硬くする方が二者を喰 付かせないで湯止りが良くなるものと考えられてい る. 殊汇高温での喰付きを防止するためにストッパー を粘土一黒鉛系にすることが各所で研究されている。

大型鍋用のストッパーはまだ一部 アメリカ品が使用されて特り，年間 約 5 万ドルの外貨が消費されてい る・この輸入品に匹敵するノズル， ストッパーの研究が現在各所で行わ れている。

第 3 表々外国品と本邦製のストッ パー品質の一例である.

第 4 表は同様ノズル品質の一例で ある。

ストッパーとしては高温度で完全 に rigid のものであれば理想的で あるが，実現がなかなか困難である ので，作業条件下で適当の粘性を有 し刍裂を生ぜず均一に減るものが良 第 4 表 ノズル品質の一例

\begin{tabular}{|c|c|c|c|c|c|c|c|}
\hline & & & & & 本 & 邦 & 繁 \\
\hline & & & & & A 社 & B社 & $\mathrm{C}$ 社 \\
\hline & $\left(\mathrm{SiO}_{2}\right.$ & $\%$ & 62.52 & 56.06 & 63.04 & 60.74 & 56.74 \\
\hline & $\mathrm{Al}_{2} \mathrm{O}_{3}+\mathrm{TiO}_{2}$ & $\%$ & 27.83 & 40.38 & 29.44 & 32.25 & 39.17 \\
\hline & $\mathrm{Fe}_{2} \mathrm{O}_{3}$ & $\%$ & 3.92 & 3.03 & 2.77 & 3.04 & 2.83 \\
\hline & $\mathrm{CaO}$ & $\%$ & 1.16 & 0.08 & 1.09 & 0.34 & 0.65 \\
\hline & $\mathrm{MgO}$ & $\%$ & 1.17 & 0.12 & 1.18 & 0.52 & 0.35 \\
\hline & アルカリ\% & & 2.52 & - & - & - & 2.02 \\
\hline & 度 $\mathrm{SK}$ & & $20 \sim 27$ & 32 & 28 & 27 & 32 \\
\hline & 重 & & 2.10 & 2.03 & 2.07 & 2.02 & 2.11 \\
\hline & 掛 比重 & & 2.60 & 2.40 & 2.51 & 2.51 & 2.59 \\
\hline 見 & 掛気孔率 & $\%$ & 19.1 & 15.5 & 17.2 & 19.8 & 18.8 \\
\hline & 封気孔率 & $\%$ & 0.4 & - & - & 4.2 & 一 \\
\hline & 気孔率 & $\%$ & 19.5 & - & - & 24.0 & - \\
\hline & 宿強さ $\mathrm{kg} / \mathrm{cm}^{2}$ & & 406 & 430 & 820 & 605 & - \\
\hline & $\mathrm{T}_{1}$ & & 1065 & 1330 & 1125 & 1130 & 1232 \\
\hline & $\begin{array}{l}3 / \mathrm{cm}^{2} \\
\text { 䡮化点 }\end{array} \mathrm{T}_{2}$ & & 1144 & 1425 & 1230 & 1150 & 1315 \\
\hline & $\mathrm{T}_{3}$ & & 1236 & 1510 & 1430 & 1315 & 1550 \\
\hline
\end{tabular}

いとされている。そしてノズルと喰付かないものすな わち Seating が良いもので, 湯洩れのないものが良 いとされている. そのためシャモット質で適当のもの が作られれば良いが，シャモット質だけで不適当であ れば上表のように粘土一黒鉛系, 粘土-SiC 系, 粘土一 黒鉛-SiC 系のbのが作られている。

ノズルはむしろ軟いものが多いのが現状であって， このうらブローチング性のものとブローチングしない ものがある.ノズルの形状はストッパーとの組合わ せ，鍋の容量や注入時間その他の造塊作業の諸条件飞 合致するように定めなければならない。ノズルの形状 の設計にあたり，高温と掓るノズルの性質と造塊作 業条件の両者を十分滄藘しないと失敗する例が多 
い. ここに今後の重要な研究課題がある.

ブローチング性ノズルは終戦後に外国の煉瓦が輸入 されて始めて直面した問題であるが，このブローチン グ特性については基礎研究が必要であると思う. 第 4 〜 6 図は品川白煉瓦社研究室で調査して数字である.

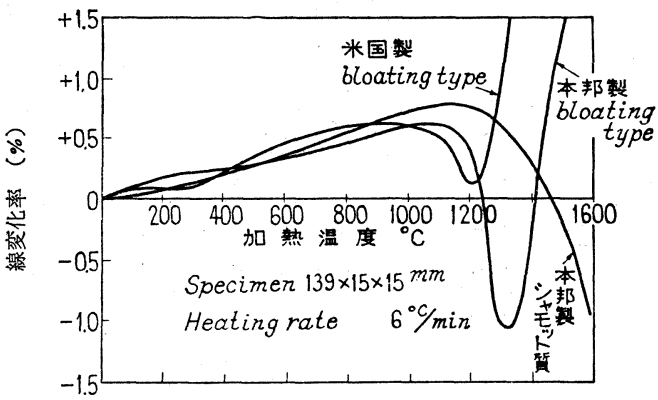

第4図ノズルの高温加熱線変化曲線

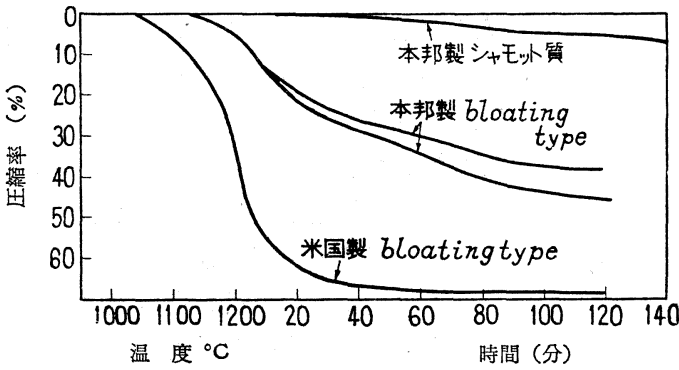

第 5 図荌ノズ荷重軟化曲線

(Load $10 \mathrm{~kg} / \mathrm{cm}^{2}$ 保持温度 $1200^{\circ} \mathrm{C}$ )

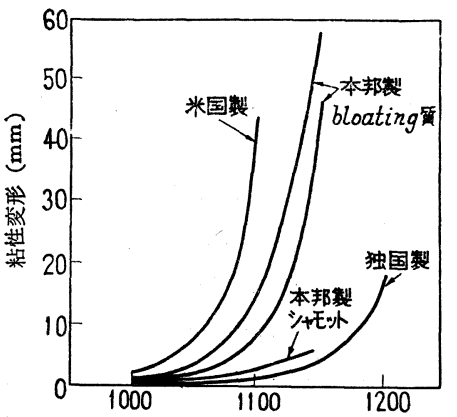

第 4 図は1600 ${ }^{\circ} \mathrm{C}$ 近くまで加 熱した場合の膨 脹収縮を測定し たもので,アメ リカ製のものは $1200^{\circ} \mathrm{C}$ からブ ローチングを始 め内地製のもの

温 度 ${ }^{\circ} \mathrm{C}$

は $1200 \sim 1300$ 第 6 図ノズルの粘性変形曲線 ${ }^{\circ} \mathrm{C}$ にかけて一 度収縮した後にブローチングを始める．このブローチ ングの発生温度，ブローチングするまでの収縮とその 温度，ブローチングする場合の気泡の形状等が重要な 問題点ではないかと思われる。これらに関して適当な 条件を探求して，これに合致した原料を選択し適切な 製造方法を定むのべである。

第 5 図は $10 \mathrm{~kg} / \mathrm{cm}^{2}$ の荷重、下に $1200^{\circ} \mathrm{C}$ 飞保持し た場合の荷重軟化曲線で，従来のシャモット質はほと んぞ軟化しない.アメリカ製のものは軟化が早く, 本 邦製のものはその中閔にある. いわゆる軟化の点から 見れば輸入品が軟化点の低い特徴を持っている。
第 6 図は第 7 図に示す装置を使用して求めたノズル の粘性変形の測定結果を示している. 高温度に括ける 粘性はノズルの操業上相当重要視さるべき特性と考え られるので測定したわけである。

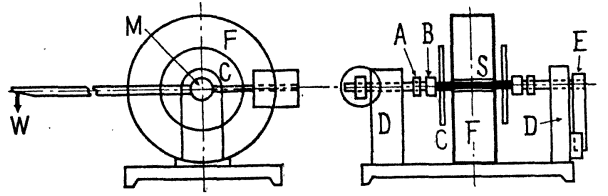

A 水冾管 $\mathrm{B}$ 試料把持器 $\mathrm{C}$ 水冷管 $\mathrm{ID}$ 支持台（ペアリンク付）

$\mathrm{E}$ 試料固定器 $\mathrm{F}$ 炬 $\mathrm{M}$ ミラー $\mathrm{S}$ 試料

耐火物捩り強度試験装置

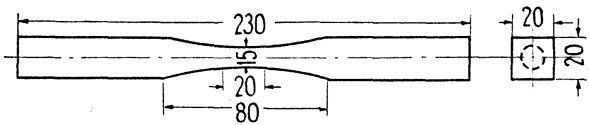

㧖り強度測定試料

第 7 困

以上の数值からはまだ結論は得られていないが，煉 瓦製造者側に括けるこの種特性試験と鉄鋼会社側の使 用実績とから相まって追求が進められればノズルの問 題も解決されるのではないかと考えられる. この点両 者の密接な共同研究が望ましい。

ドイッのノズル，ストッパーの特性はアメリカ品の 特性と大分趣きを異にしているが，果していずれが良 いかはわれわれとしてはわが国の原料事情を考慮して 研究すべき今後の問題と思われる.

以上の外，造塊用煉瓦としてはスリーブと湯道煉瓦 があるが今回は省略する。

\section{交献}

1) 毛利, 藤井, 耐火物工業, 22,23 集 6-39 41 (1954); K.O. Zimmer, Stahl u. Eisen, 73 [7] 411-416 (1953)

2) L. Halm, Trans. Brit. Ceram. Soc., 54 [9] 507-542 (1955)

\section{通産省で窯炉の調查}

通産大臣官房統計部では生産と不可分の関係にある 培炉の種類別基数と使用年数を調査して実態を把握 し, 統計と行政施策の基礎資料とする目的で, 調查範 册はガラス製品, 光学ガラス, ガラス繊維, 耐火棟 瓦, 赤棟瓦, 陶磁器 ( 4 人未満子含む), 珐瑯鉄器, 研削砥石, 炭素製品, の9 業種の工場全部について行 5 .

な招調查の期日は 10 月末現在で今年限り, 調査事 項は突炉の種類と数, 使用年数, 光学ガラスとガラス 製品の熔融能力, 赤煉瓦の陞出能力, 陶磁器の輸出振 興のための基礎資料を併せて調查する。 